

\section{about the organisations}

\section{ICIMOD}

The International Centre for Integrated Mountain Development (ICIMOD) is an independent 'Mountain Learning and Knowledge Centre' serving the eight countries of the Hindu Kush-Himalayas - Afghanistan

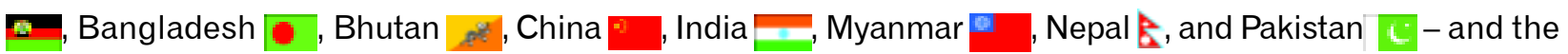
global mountain community. Founded in 1983, ICIMOD is based in Kathmandu, Nepal, and brings together a partnership of regional member countries, partner institutions, and donors with a commitment for development action to secure the future of the Hindu Kush-Himalayas. The primary objective of the Centre is to promote the development of economically and environmentally sound mountain ecosystems and to improve the living standards of mountain populations.

ICIMOD can be contacted at

4/80 Jawalakhel, GPO Box 3226, Kathmandu, Nepal

Tel: +97715525313

Fax: + $97715524509 / 5536747$

E-mail: distri@icimod.org.np

Online: http://icimod.org

\section{GERES}

The Renewable Energy and Environment Group (GERES) is a French NGO created in 1976. GERES works in a dozen countries in Asia and Africa promoting renewable energy resources and energy efficiency through a development process controlled by the local people. GERES encourages the use of local resources with the aim of respecting the environment and providing well-balanced development schemes.

GERES has been working for 20 years for the benefit of local development in the Hindu KushHimalayas $(\mathrm{HKH})$, with a focus on promoting well-adapted and eco-friendly technologies. The main field activities are concerned with energy saving (passive solar buildings, improved stoves) and income generation (solar greenhouses, solar poultry farming, ecotourism, food processing, processing wool). GERES first project in the HKH was set up in 1982 in Ladakh (India). At present, GERES supports local NGOs in India, Nepal, China, and Afghanistan in a variety of activities.

Our strategy is based on privileged partnerships with various government and non-government organisations and the participation of the local population. Our projects aim at enabling local communities to earn additional income to access modern services while preserving the fragile environment of the Hindu Kush-Himalayan region.

\section{GERES can be contacted at}

2, cours Foch, 13400 Aubagne, France

Tel: +33442185588

Fax: +33442030156

E-mail: geres@free.fr

Online: http://geres.free.fr/ 


\title{
Solar Greenhouses for the Trans-Himalayas A Construction Manual
}

\author{
Vincent Stauffer \\ with \\ Tashi Tokhmat, Dorge Raftan, Gulam Razul (LEHO) \\ Christophe Viltard, Laetitia Rivagorda, Philippe Rynikiewicz \\ Benoit Giraud, Claude Tournellec, Rodolphe Castelani \\ Thomas Mansouri, Alain Guinebault (GERES)
}

International Centre for Integrated Mountain Development (ICIMOD)

Agriculture and Rural Income Diversification (ARID)

Kathmandu, Nepal

Renewable Energy and Environment Group (GERES)

Aubagne, France

April 2004 


\section{Copyright $\odot 2004$}

International Centre for Integrated Mountain Development

GERES (Renewable Energy and Environment Group)

All rights reserved

\section{Photo credits}

All the photographs credited to GERES, except $N^{\circ} 41$ credited to ATA

\section{Published by}

International Centre for Integrated Mountain Development

G.P.O. Box 3226

Kathmandu, Nepal

with

GERES (Renewable Energy and Environment Group)

2, cours Foch, 13400 Aubagne, France

\section{ISBN 9291158321}

\section{Editorial Team}

A.Beatrice Murray (Editor)

Dharma R. Maharjan (Technical Support and Layout Design)

\section{Printed and bound in Nepal by}

Quality Printers Pvt. Ltd., Kathmandu, Nepal

The views and interpretations in this paper are those of the contributor(s). They are not attributable to the International Centre for Integrated Mountain Development (ICIMOD) or GERES and do not imply the expression of any opinion concerning the legal status of any country, territory, city or area of its authorities, or concerning the delimitation of its frontiers or boundaries, or the endorsement of any product. 


\section{FOREWORD}

Food security remains the major preoccupation of mountain communities in many parts of Asia, especially in the higher altitude and more remote parts of the Hindu Kush-Himalayan region. The climate in this region of the trans-Himalayas is very harsh: winter temperatures can fall below $-30^{\circ} \mathrm{C}$, and precipitation is low. The natural resources are limited, and farmers rely on sheep, goats, cattle and yak as their main source of survival, with limited subsistence agriculture on very small landholdings focused mainly on cereals. In the winter, snowfall blocks the high passes and roads are closed, and the population must rely almost entirely on its own resources for survival.

Mountain communities have survived for centuries in this environment, but population increases, environmental pressure, and political changes and limitations to movement are increasing the challenge. At the same time, expectations and demands are increasing, as contact with the outside world and more widespread education raise people's awareness of the possibilities and potential benefits elsewhere. The result is increased out-migration, especially of the young and strong; reduced capacity of those left behind to use the land; loss of community, culture, and the indigenous knowledge of how to survive in these harsh conditions; and an influx of people to urban areas to join the growing ranks of the poor and rootless.

The Renewable Energy and Environment Group GERES, supported by its partners in development (European Commission, French Ministry of Foreign Affairs, and others) works with mountain communities to help them establish tools and processes that strengthen and develop local potentials, improve livelihoods, and provide people with better options for remaining in their home areas. Many innovative tools have been developed, improved, and adapted for local use. GERES, working with Indian, Chinese, Nepalese, and Afghan NGOs, has focused on technologies for saving energy (passive solar buildings and improved stoves to reduce consumption of wood and other fuels), and generating income (solar greenhouses, solar poultry farming, processing of food and wool).

One of the major challenges is to help communities use the inactive winter period to increase food security and generate additional income. Fortunately, one resource that the trans-Himalayan area has in abundance is sunshine, especially in winter. Solar radiation can be used to improve the quality of life in many ways. Potential benefits include warming houses, schools, dispensaries and handicraft centres, and developing off-season agricultural activities such as composting, greenhouse production, and poultry farming. This manual focuses on the construction of passive solar greenhouses that enable vegetables to be grown during winter in the high altitude areas of the trans-Himalayas.

The International Centre for Integrated Mountain Development (ICIMOD) works to improve the livelihoods and security of the mountain communities of the Hindu Kush-Himalayas (HKH). Improving the productivity and sustainability of mountain agriculture, reducing fuel consumption, and reducing environmental damage are central to its activities. As a part of its programme, ICIMOD has had a major focus on rural technologies and alternative energy approaches, including hosting a series of national workshops on passive solar building technologies in four of the countries of the $\mathrm{HKH}$. The new Integrated Programme on Agriculture and Rural Income Diversification (ARID) focuses on high value products, rural enterprises, and renewable energy options, among others. Thus ICIMOD is delighted to have had this opportunity to support GERES in the development of this manual on solar greenhouse technology, and to be able to make this information available to a wider community.

GERES and ICIMOD both hope that this manual will prove useful to the many NGOs and other technical organisations who are working with communities and farmers in the $\mathrm{HKH}$ region to improve living standards and conditions, and ultimately that increased access to winter vegetables and exotic summer produce will improve the quality of life and income generation opportunities of many of the small farmers in some of the most marginalised areas of the Hindu Kush-Himalayas.

Alain Guinebault
Director
GERES

Alain Guinebault GERES

\author{
J. Gabriel Campbell \\ Director General \\ ICIMOD
}




\section{ACKNOWLEDGements}

The greenhouse design proposed in this handbook is the result of improvements made by NGOs and by farmers themselves of a design initially proposed by GERES. The main contributors to this design evolution were marginal farmers of the trans-Himalayan areas, who suggested practical improvements that reduce the investment cost and construction requirements and ensure that the design is appropriate for the resources available in these high mountain areas.

LEHO (Ladakh Health and Environment Organisation) was the first non-government organisation (NGO) to experiment with the model; this NGO did a tremendous amount of work to improve the design and to train carpenters and masons to build greenhouses in remote areas.

The following NGOs contributed greatly to adapting the initial design to suit specific local contexts.

Ladakh (Jammu and Kashmir, India)

- LEHO (Ladakh Health and Environment Organisation)

- LEDeG (Ladakh Ecological and Development Group)

- LNP (Leh Nutrition Project)

- CRO (Chief Representative Organisation)

Lahaul and Spiti (Himachal Pradesh, India)

- Himachal Pradesh Government through the Watershed Project

- Pragya

- Dawa Development

Qinghai (China)

- ATA (Appropriate Technology for Asia)

Badakshan, Hazara Jat, Lowgar, and Parwan (Afghanistan)

- Ministry of Animal Husbandry and Agriculture

- AKDN (Agha Khan Development Network)

- AFRANE Developpement (Amitié franco-afghane)

- SOLIDARITES

Mustang (Nepal)

- ATA (Appropriate Technology for Asia)

The experimentation and implementation, and publication of the manual, would not have been possible without the financial support of the European Commission, French Ministry of Foreign Affairs,

SOLIDARITES, Frères de nos Frères, and ATA, in particular we would like to acknowledge the European Commission which has been supporting field projects in Ladakh, Lahaul \& Spiti, Mustang, and Qinghai since 1988. We thank ICIMOD for their support and encouragement to publish the manual for wider distribution, in particular Greta Rana - Division Head, IMCO for recognising the potential value of the manual; Kamal Rijal - former Energy Specialist for his support and valuable comments; A.

Beatrice Murray - for her editorial support; Dharma R. Maharjan for layout and design; and all the other members of the publications unit.

Finally, it is important to mention that the greenhouse design and the manual itself were developed in partnership with contributions from many individuals, in particular, from GERES, Christophe Viltard and Laetitia Rivagorda, who did the agricultural experimentation; Philippe Rynikiewicz, Benoit Giraud, and Claude Tounellec, who thought of many practical improvements; Rodolphe Castelani, who did the drawings; Thomas Mansouri, who set up the manual; and Alain Guinebault, who initiated the project; from LEHO Tashi Tokhmat, Dorge Raftan, and Gulam Razul, who carried out the first trials, and suggested major improvements; Sjoerd Nienhuys of SNV who made some useful suggestions in a review of different types of greenhouses in Mustang; and all the farmers and construction workers at the different project sites whose enthusiasm, interest, and hard work helped to improve the design and ensured the project was successful. 


\section{Units ANd Geometry}

$\begin{array}{ll}1^{\prime} & 1 \mathrm{ft}=1 \mathrm{foot}=0.3048 \mathrm{~m} \\ 1^{\prime \prime} & 1 \text { inch }=2.54 \mathrm{~cm} \\ 1 \mathrm{~cm} & 1 \text { centimetre } \\ 1 \mathrm{~m} & 1 \text { metre }=100 \mathrm{~cm} \\ { }^{\circ} \mathrm{C} & \text { Degree Celsius } \\ \varnothing & \text { diameter }\end{array}$




\section{Contents}

\section{Introduction}

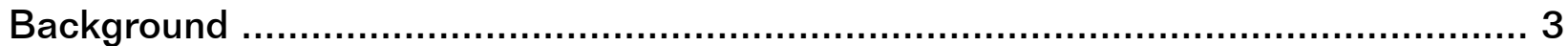

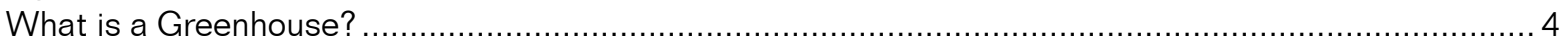

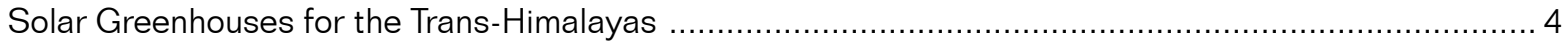

\section{Part A: Theory of Passive Solar Greenhouses for Cold Areas}

The Passive Solar Greenhouse Concept ............................................................. 9

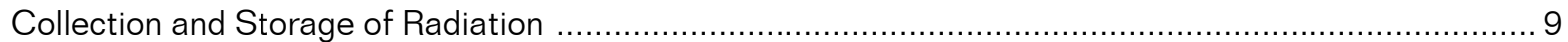

Storage, Release and Containment of Heat: the Thermal Properties of Materials ........................... 10

Principles of Solar Greenhouse Design ........................................................... 11

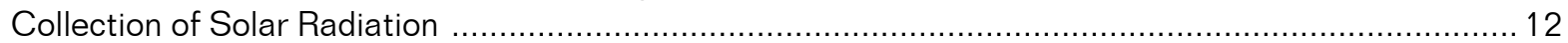

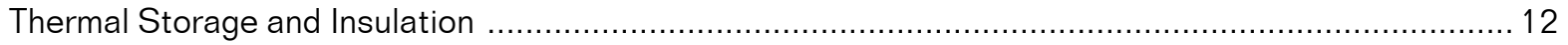

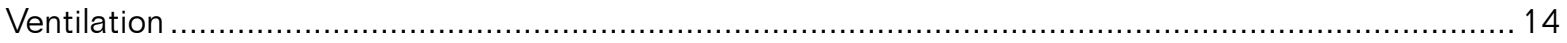

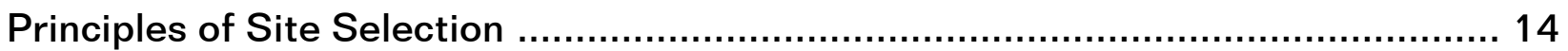

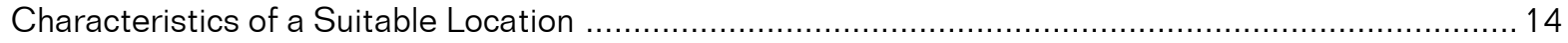

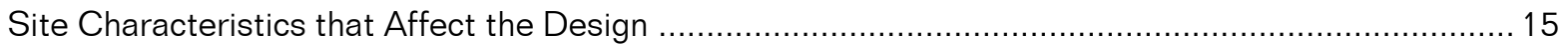

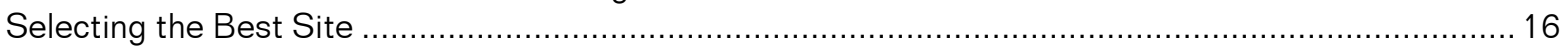

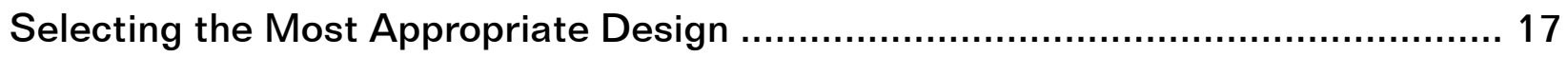

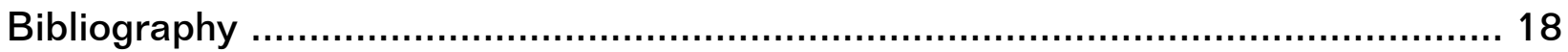

\section{Part B: Technical Guidelines for Building a Greenhouse}

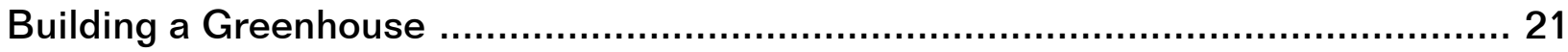

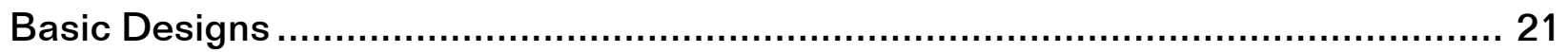

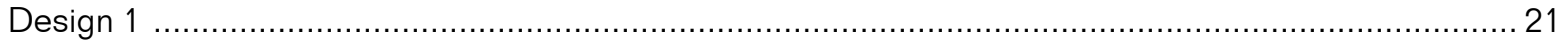

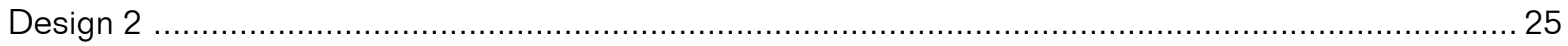

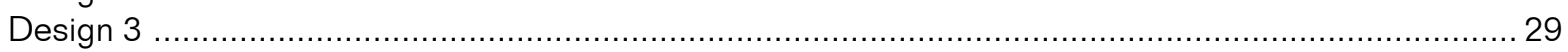

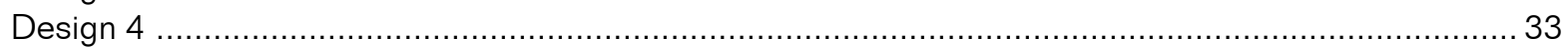

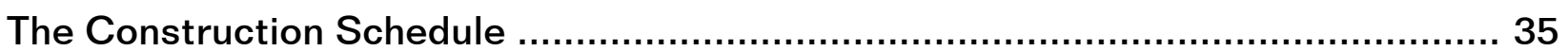

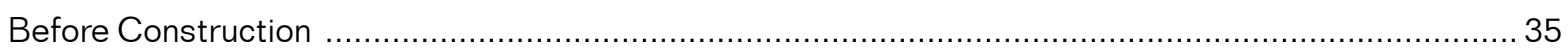

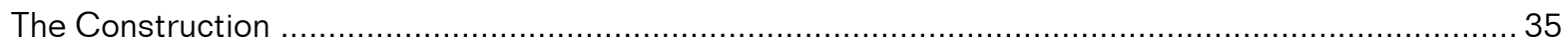




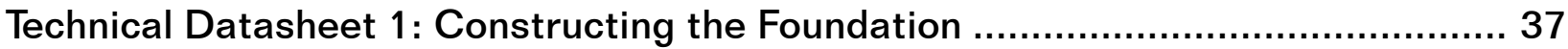

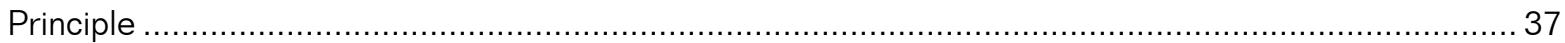

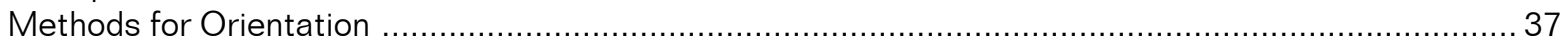

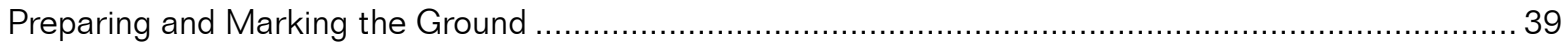

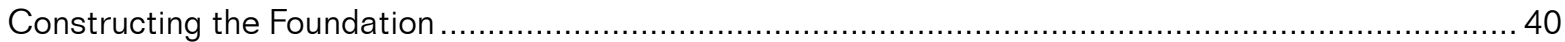

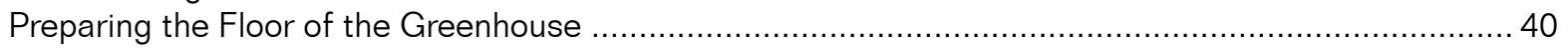

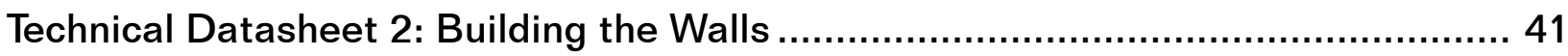

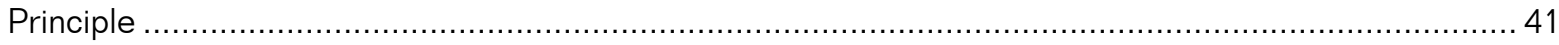

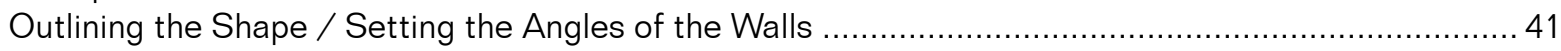

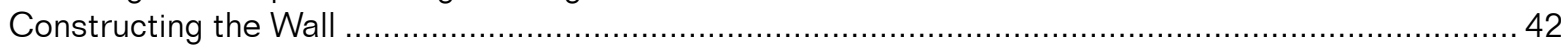

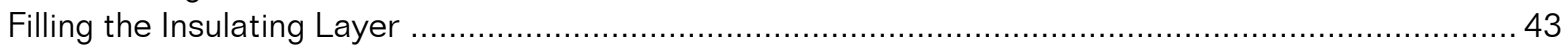

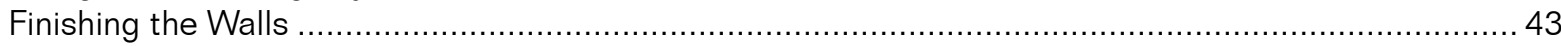

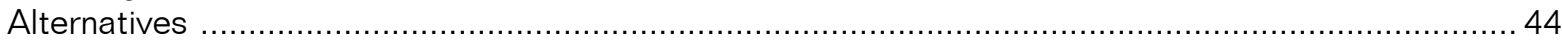

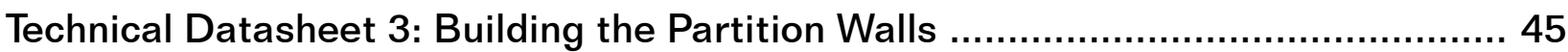

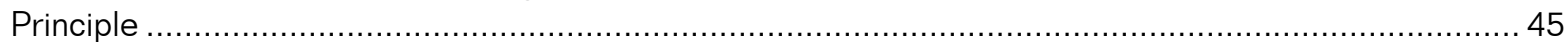

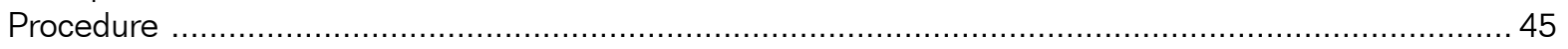

Technical Datasheet 4: Making and Installing the Access Door ........................ 47

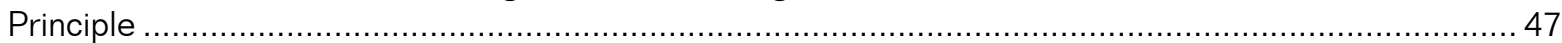

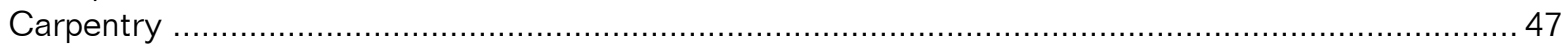

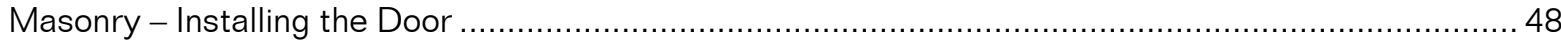

Technical Datasheet 5: Making and Installing the Wall Ventilator ........................49

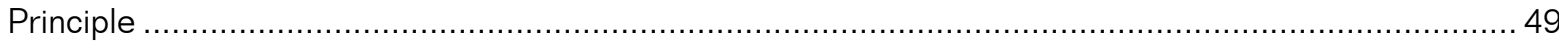

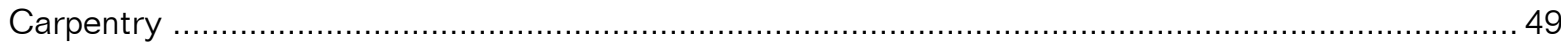

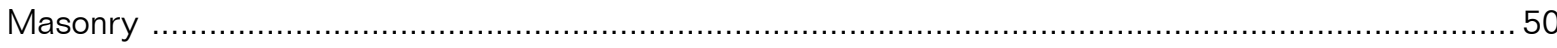

Technical Datasheet 6: Constructing the Roof .......................................... 51

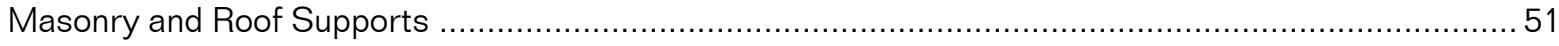

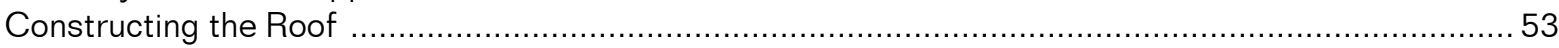

Technical Datasheet 7: Making and Installing the Roof Ventilator..................... 55

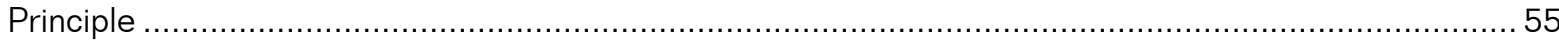

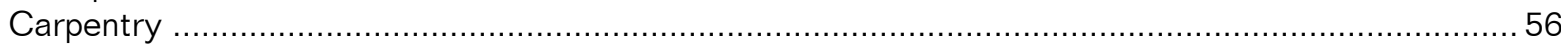

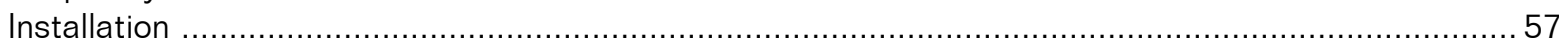

Technical Datasheet 8: Installing the Polythene Sheet ................................. 59

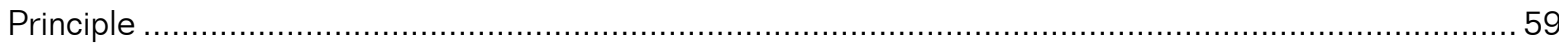

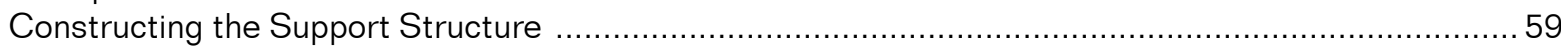

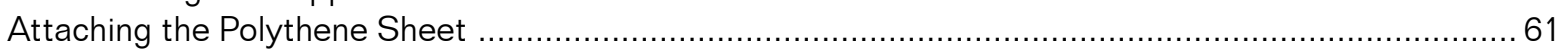

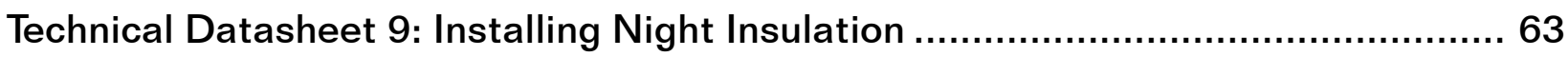

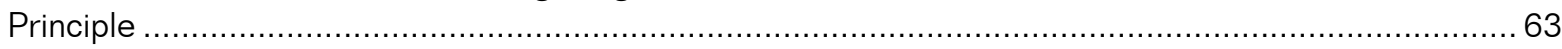

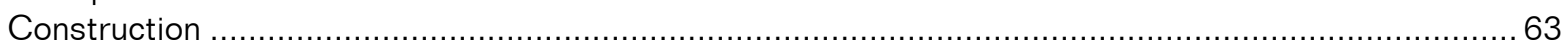

Technical Datasheet 10: List of Materials .................................................. 65

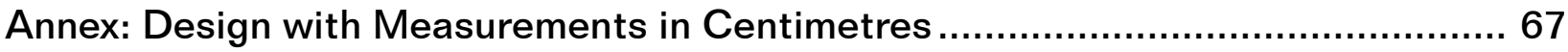

List of Materials ........................................................................... 71 